\title{
Forensic Pathology of Neonatology in a Developing Country
}

\author{
Wilson I B Onuigbo* \\ Department of Pathology, Medical Foundation \& Clinic, Nigeria
}

*Corresponding author: Wilson I B Onuigbo, Department of Pathology, Medical Foundation \& Clinic, 8 Nsukka Lane, Enugu-410000, Nigeria

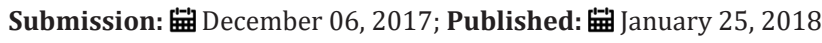

\begin{abstract}
The neonate is defined as a child less than a month old. Interest in the subject is so wide that glimpses of it are available from countries as variable as England, Iran, Italy, Kenya, The Netherlands, Norway, South Africa, and Turkey. Therefore, this paper is from Nigeria. It is deemed to be worthy of documentation, especially in terms of the preponderance of males.
\end{abstract}

Keywords: Neonatology; Death; Pathology; Epidemiology; Males; Nigeria

\section{Introduction}

According to the Merriam-Webster's Collegiate Dictionary, [1] the neonate is defined as a child less than a month old. It is such an interesting subject that it has been studied as widely as in England, Iran, Italy, Kenya, The Netherlands, Norway, South Africa, Turkey and USA [2-10]. Accordingly, the present paper proposes to study it from the vantage point of a developing community.

\section{Investigation}

It has been stated that the establishment of a histopathology data pool facilitates epidemiological analysis. [11] Therefore, since such a pool was established in South Eastern Nigeria among the Ibo or Igbo ethnic group, [12] it became possible, as the pioneer pathologist, to investigate personally its neonatal deaths. The tabular form is useful.

\section{Results}

Sex and lesions detected is shown in Table 1.

Table 1: Sex and lesions detected.

\begin{tabular}{|c|c|}
\hline Sex & Disease \\
\hline Male & Congenital heart disease \\
\hline Male & Atelectasis \\
\hline Male & Atelectasis \\
\hline Male & Congenital brain disease \\
\hline Male & Neonatal jaundice \\
\hline Female & Atelectasis \\
\hline
\end{tabular}

\section{Discussion}

The male factor has stood out clearly here. Incidentally, there is preference of male children in the Igbo community. Thus, it suffices here to cite the anthropological work itself [12]. For instance, "there is a rite which corresponds to a form of dedication" and "is restricted solely to boys."

An oddity was the neonatal death of rupture of the normal splee [13]. Also, interesting was the report of " 2 cases of newborn infants perinatal arterial stroke that may have been associated with in utero exposure to codeine" [14]. Therefore, let me close with their advice thus: "Physicians should ask about maternal medication use, including codeine-containing cough preparations, when evaluating newborn infants with evidence of cerebral infarction."

\section{References}

1. Merriam-Webster's Collegiate Dictionary. Springfield, Mass: MerriamWebster, Inc. (12 ${ }^{\text {th }}$ Edn.), P. 831.

2. Hutchon DJR (2016) Ventilation, chest compression and placental circulation at neonatal resuscitation-ILCOR recommendation 2015. J Paediatr Neonatal Dis 1(1): 104.

3. Fallahi M, Vaghefi SS, Makhmalbaf M (2016) Analysis of negligence in field of neonatology in medical commissions office in Tehran, Iran. Intl J Med Toxicol Forensic Med 6(3): 135-141.

4. d'Aloja E, Muller M, Paribello F (2009) Neonatal asphyxia and forensic medicine. J Matern Fetal Neonatal Med 22(3): 54-56.

5. Musoke RN (2016) The long road to newborn survival: Working with parents, families and communities to reduce preventable neonatal deaths. Pediatr Neonat Biol 1(1): 000105.

6. Dorscheidt JHH (2013) Legal aspects of end-of-life decisions in neonatology. Legal Forensic Med pp. 1175-1200. 
7. Alfsen GC, Hernæs L (2013) Dead infants and unmarried women--from forensic pathology reports 1910-12. Tidssk Norske Laegefore Med 133(23-24): 2493-2497.

8. Wainwright HC (2006) My approach to performing a perinatal or neonatal autopsy. J Clin Pathol 59(7): 673-680.

9. Turan N, Pakis I, Yilmaz R, Gunce E (2013) Macroscopic and microscopic findings of infant lung in case of live or still birth. Sci Res Essays 8(21): 867-874.

10. Iffy L, Varadi V, Papp E (2001) Untoward neonatal sequelae deriving from cutting of the umbilical cord before delivery. Med Law 20(4): 627634.
11. Macartney JC, Rollaston TP, Codling BW (1980) Use of a histopathology data pool for epidemiological analysis. J Clin Pathol 33(4): 351-353.

12. Basden GT (1966) Niger Ibos. Lond: Cass.

13. Acar K, Cinbis M (2000) A neonatal death due to rupture of the normal spleen. Internet J Pediatr Neonatol 2(1): 1-4.

14. Reynolds EW, Riel-Romero RMS, Bada HS (2007) Neonatal abstinence syndrome and cerebral infarction following maternal codeine use during pregnancy. Clin Pediatr 46(7): 639-645. 